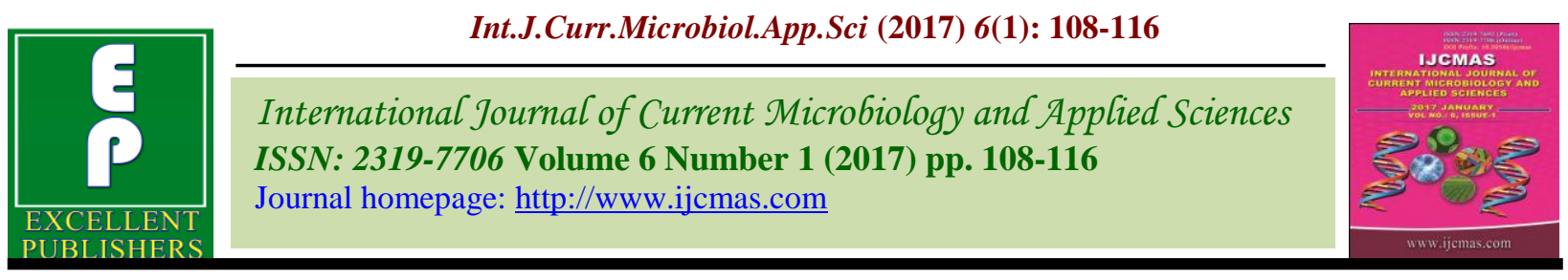

Original Research Article

http://dx.doi.org/10.20546/ijcmas.2017.601.014

\title{
Studying Efficiency Inhibition of Some Medicinal Plant Extracts against Some Fungal
}

\author{
Hasan Kadhim Ali, Ahmed Malik Jumaah* and Ahmed Sadoon Hassian \\ College of Agriculture, Misan University, Misan City, Iraq \\ *Corresponding author
}

A B S T R A C T

Ke y words

Plant extracts (basil, mint,dill), fungal,

Penicillium sp.,

Aspergillus niger,

Rhizopus sp,

Fusarium sp.

Article Info

Accepted:

12 December 2016

Available Online:

10 January 2017
The present study impression concentrations different from extract alcohol some of the medicinal plants mint (Mentha spicata L.) basil (Ocimum basilicum L.) Dill (Anethum graveolens) agent isolation the fungal and which included (Penicillium sp. Rhizopus sp Fusarium sp. Aspergillus niger) where showed the results if extract Dill give higher inhibition against fungal comparative others the extracts and got inhibition complete at concentration $1000 \mathrm{mg} / \mathrm{ml}$ against fungal Penicillium sp. Rhizopus sp and Aspergillus. niger rate $100 \%$ while fungal Fusarium sp.of rate $97.12 \%$ on follow extract peppermint at concentration 1000 $\mathrm{mg} / \mathrm{ml}$ got rate inhibition $98.31 \%, 93.41 \%$ against fungal Penicillium sp. Aspergillus.niger on respectively and got less rate inhibition against fungal for extract basil comparative others the extracts they got at concentration $1000 \mathrm{mg} / \mathrm{ml}$ rate inhibition $89.47 \%, 85.78, \% 80 \%, 77.59 \%$ against fungal Penicillium $s p$. Aspergillus niger, Rhizopus sp, Fusarium sp. on respectively.

\section{Introduction}

Increase the attention in the years of least a plants and medicinal herbs to employ of sources main production of the medicinal drugs or uses medicinal plants have no doubt remained the major sources of traditional medicine worldwide Accordingly, attention of scientists and researchers have been attracted towards developing new antibiotics that will curtail the increasing drug resistance among microorganisms (Masih et al., 2014) plants used for traditional medicine generally contain a number of compounds which may be a potential natural antimicrobial combination and which may serve as an alternative, effective cheap and safe antimicrobial agents for treatment of common microbial infections (Schimmer et al., 1994; Mathur and Goyal, 2011). Medicinal plants were used as excellent antimicrobial agents because it poses a variety of chemical constituent is nature recently much attention has directed towards extracts and biologically active compounds isolated from popular plant species. Traditional medicine is an important source of potentially useful are a source of great economic value all over the world. Nature has bestowed on us a very rich botanical wealth and large number of diverse 
type of plants grow in different parts of the country. Plant products still remain the principal source of pharmaceutical agents used in traditional medicine (Prince and Prabakaran, 2011).

Spearmint( Mentha spicata L.) or peppermint with vernacular name of "nana felfeli", a plant from the Labiatae family, is traditionally used as an antiseptic, stimulant, carminative agent or it is further used as a flavoring agent in cosmetic and pharmaceutical industries throughout the world (Mahboubi and Kazempour, 2013).

According to its antiseptic activities, there are some investigations on its antimicrobial activities. mint oil showed good antimicrobial activity against Aspergilus niger, Rhizopus solani and Alternaria alternate (Carretto et al., 2010). The mint plant is an aromatic perennial herb cultivated in most part of the world, have traditionally been used in folk medicine. Leaves of mint plant are frequently used in herbal tea and for culinary purpose to add flavour and aroma. The distinctive smell and flavor, a characteristic feature of Mentha spp. is due to the naturally occurring cyclic terpene alcohol called menthol (Pramila et al., 2012).

Basil (Ocimum basilicum L.) of the family Lamiaceae. Ocimum (from Greek ozo for smell) is appropriate for the genus since its various species are known for their peculiar strong odours. Basilicum is the Latin translation of the Greek basilikon meaning king and due perhaps the same reason the herb is called "Herbe Royale" in French (Khair-ul-Bariyah et al., 2012). Plants have long been part of Iraqi cultures as they were consumed regularly as part of the diet. These plants were eaten raw as salad, or used in cooking to flavor the dishes. Some of these plants have been used as folk remedies for the treatment of ailments such as diabetes, high blood pressure, arthritis and fever as well as health tonic (Salim et al., 2014). $O$. Basilicum has been extensively studied for its medicinal properties which include antibacterial, anti-inflammatory, antiproliferative/anticancer, antioxidant, antiviral and antifungal activities (Zaker et al., 2014).

Dill (Anethum graveolens) is grown as an irrigated annual crop both in temperate and tropical regions. A large number of varieties are known in cultivation (Randhwa et al. 1995). It is characterized by hollow stems, blue-green leaves and yellow-flowering flat compound umbels, which produce a dried ripe fruit commonly called seed.

Flowers and seeds represent the commercial product (Carrubba et al., 2002). Dill has also been used as anticancer; anti-diabetic; antioxidant; antisecretory; and antimycobacterial (Zheng et al., 1992; Hosseinzadeh et al., 2002; Al-Ismail et al., 2004; Panda et al., 2008).

\section{Materials and Methods}

\section{Preparation of simple}

Leaves plants were collected from local city markets in misan/Iraq (mint, basil, dill). The plant material was thoroughly washed with clean water to remove soil and other dirt and Mill the leaves in miller for powder and putting powder both plant in tins glassy of time the extraction.

\section{Microorganisms uses in studying}

Uses in this study isolations Microorganisms different from isolations fungals and use organisms testing Microorganisms detection activity inhibition of extraction plants and source this isolations Penicillium sp. Fusarium sp. Rhizopus sp. Aspergillus niger from department sciences biology/college sciences /university misan. 


\section{Preparation of Plant Extracts}

The air-dried plant materials were separately extracted twice at room temperature with ethanol $95 \%(500 \mathrm{ml} / 100 \mathrm{~g}$ of plant material each run). The final ethanol extract of each plant part was filtered using filter paper (Whatman) and was evaporated under vacuum at $40^{\circ} \mathrm{C}$ using rotary vacuum evaporator resultant residues from the different plants parts and were stored at -20 ${ }^{\circ} \mathrm{C}$ for further analysis (Mahasneh, 2002).

Activation isolations the fungal include isolations Penicillium sp. Fusarium sp. Rhizopus sp. Aspergillus niger and that transfer $(1 \mathrm{ml})$ from isolation on medium PDA and incubator at temperature 25 of time 5 day (Bobbarala et al., 2009).

Study efficiently the inhibition for extraction plants against fungal.

The plant extracts were added to PDA (at $45^{\circ} \mathrm{C}$ ) to give a final concentration 300,500 , 700 and $1000 \mathrm{mg} / \mathrm{ml}$ for each extract were poured in petri dishes $(8 \mathrm{~cm}$ in diameter). Ethanol was added to medium in control plates. Then, inoculum discs $(5 \mathrm{~mm}$ in diameter) Ethanol was added to medium in control Tube. from 5 days growing cultures of fungal placed in the center of petri plates containing PDA and extracts.. The plates were incubated in $27^{\circ} \mathrm{C}$ (Mahboubi and Kazempour, 2013). The percentage of fungal growth inhibition was calculated as (Pandey et al., 1982) formula:

Growth inhibition\% $=[$ (growth in control growth in sample)/growth in control] $\times 100$

6. Statistical Analysis: Data regarding two parameters (concentration and medicinal plants) were analyzed statistically using SAS program with completely randomized design (CRD). Inhibition of radial fungal growth was examined using analysis of variance
(ANOVA) and means were compared by the test of least germination of fungal.

\section{Results and Discussion}

Inhibition types some fungal of uses extracts of the medicinal plants

\section{Inhibition of fungal of the extract peppermint}

Shown in Table(1) ) and Fig.(1)the influences Inhibition of the extract peppermint against fungal Penicillium sp, Fusarium sp, Rhizopus sp, Aspergillus niger of concentration $(300,500,700,1000 \mathrm{mg} / \mathrm{ml})$ and showed extract peppermint Capability high on Inhibition both Penicillium sp,Aspergillus niger at concentration $(1000 \mathrm{mg} / \mathrm{ml})$ of rate Inhibition reach $\% 98$ and $\% 93$ on respectively. And influences Inhibition of the extract peppermint against Penicillium sp, Aspergillus niger at concentration $(300,500$, $700 \mathrm{mg} / \mathrm{ml}$ ) of rate Inhibition reach 21.56, $17.10 \%, 60.89 \%, 54.29, \% 89.46 \%, 86.71 \%$ on respectively, and reach less Inhibition against Fusarium sp, Rhizopus sp at concentration $(300 \mathrm{mg} / \mathrm{ml})$ of rate $\% 11.78, \% 15.44$ on respectively were found significant $(p<0.05)$ between concentration for extract mint.

If mint plant have characteristic feature of antimicrobial properties because contain compounds activity cyclic terpene alcohol called menthol (Pramila et al., 2012). From these results, it was observed that for extract mint his Capability Inhibition against Penicillium sp do much from lasting fungal. $M$. piperita extract exhibits antimicrobial activity against a range of fungi including Alternaria alternate, Aspergillus niger, Penicillium funiculosum, Trichophyton rubrum. this result approximate when of reach (Jakowinko et al., 2010) at studying about mint against both Aspergillus niger, Botrytis cinerea, Eurotium amstelodami, 
Eurotium chevalieri, Penicillium cyclopiumi Trichothecium roseum observed that for influences obvious the mint on growth fungal. And significant reason that to capability the extracts plant on Inhibition fungi The use of biological compounds extracted from plants may be an alternative to conventionally used fungicides to control phytopathogenic fungi, due to their being bioactive chemicals such as flavonoids, phenols, tannins, alkaloids, quinones, saponins and sterols (Manoorkarand Gach, 2014).

\section{Inhibition of fungal of the extract basil}

Shown in Table(2) and Fig.(2) the influences Inhibition of the extract basil against fungal Penicillium sp,Fusarium sp,Rhizopus sp,
Aspergillus niger of concentration $(300,500,700,1000 \mathrm{mg} / \mathrm{ml})$ and showed extract basil Capability high on Inhibition both, Penicillium sp, Aspergillus niger at concentration $(1000 \mathrm{mg} / \mathrm{ml})$ of rate Inhibition reach $89.47 \%$ and $85.78 \%$ on respectively. And influences Inhibition of the extract basil against Penicillium sp,Aspergillus niger at concentration $(300,500,700 \mathrm{mg} / \mathrm{ml})$ of rate Inhibition reach $18.67, \% 14.52 \%, 58.99 \%$, $48.76, \% 78.23 \%, 74.50 \%$ on respectively, and reach less Inhibition against Fusarium sp,Rhizopus sp at concentration $(300 \mathrm{mg} / \mathrm{ml})$ of rate $14.58 \%, 12.34 \%$ on respectively. from these results, it was observed that for extract basil his Capability Inhibition against Penicillium sp do much from lasting fungal. were found significant $(\mathrm{p}<0.05)$ between concentration for extract basil.

Table.1 Influence addition concentration different from extract mint on growth some fungal

\begin{tabular}{||c|c||c||c||c|}
\hline $\begin{array}{c}\text { Penicillium } \\
\text { Sp. }\end{array}$ & $\begin{array}{c}\text { Fusarium } \\
\text { Sp. }\end{array}$ & Rhizopus Sp. & Aspergillus niger & $\begin{array}{c}\text { Name funal } \\
\text { concentration }\end{array}$ \\
\hline \hline 21.56 & 11.78 & 15.44 & 17.10 & $\mathrm{mg} / \mathrm{ml} 300$ \\
\hline \hline 60.89 & 48.60 & 50.21 & 54.29 & $\mathrm{mg} / \mathrm{ml} 500$ \\
\hline \hline 89.46 & 76.55 & 81.39 & 86.71 & $700 \mathrm{mg} / \mathrm{ml}$ \\
\hline \hline 98.31 & 83.17 & 90.45 & 93.41 & $1000 \mathrm{mg} / \mathrm{ml}$ \\
\hline
\end{tabular}

Table. 2 influences addition concentration different from extract basil on growth some fungal

\begin{tabular}{||c|c||c||c|c||}
\hline $\begin{array}{c}\text { Penicillium } \\
\text { Sp. }\end{array}$ & $\begin{array}{c}\text { Fusarium } \\
\text { Sp. }\end{array}$ & Rhizopus Sp. & Aspergillus niger & $\begin{array}{c}\text { Name funal } \\
\text { concentration }\end{array}$ \\
\hline \hline 18.67 & 8.77 & 12.34 & 14.52 & $\mathrm{mg} / \mathrm{ml} 300$ \\
\hline \hline 58.99 & 44.82 & 45.51 & 48.76 & $\mathrm{mg} / \mathrm{ml} 500$ \\
\hline \hline 78.23 & 68.45 & 71.64 & 74.50 & $700 \mathrm{mg} / \mathrm{ml}$ \\
\hline 89.47 & 77.59 & 80.56 & 85.78 & $1000 \mathrm{mg} / \mathrm{ml}$ \\
\hline
\end{tabular}


Table.3 influences addition concentration different from extract Dill on growth some fungal

\begin{tabular}{|c||c|c|c|c||}
\hline $\begin{array}{c}\text { Penicillium } \\
\text { sp. }\end{array}$ & $\begin{array}{c}\text { Fusarium } \\
\text { Sp. }\end{array}$ & Rhizopus Sp. & Aspergillus niger & $\begin{array}{c}\text { Name funal } \\
\text { concentration }\end{array}$ \\
\hline \hline 24.51 & 15.38 & 18.54 & 20.78 & $\mathrm{mg} / \mathrm{ml} 300$ \\
\hline \hline 75.36 & 59.78 & 63.56 & 65.86 & $\mathrm{mg} / \mathrm{ml} 500$ \\
\hline \hline 95.34 & 86.19 & 90.32 & 92.13 & $700 \mathrm{mg} / \mathrm{ml}$ \\
\hline \hline 100 & 97.12 & 100 & 100 & $1000 \mathrm{mg} / \mathrm{ml}$ \\
\hline
\end{tabular}

Fig 1 Influences addition concentration different from extract mint on growth some fungal.

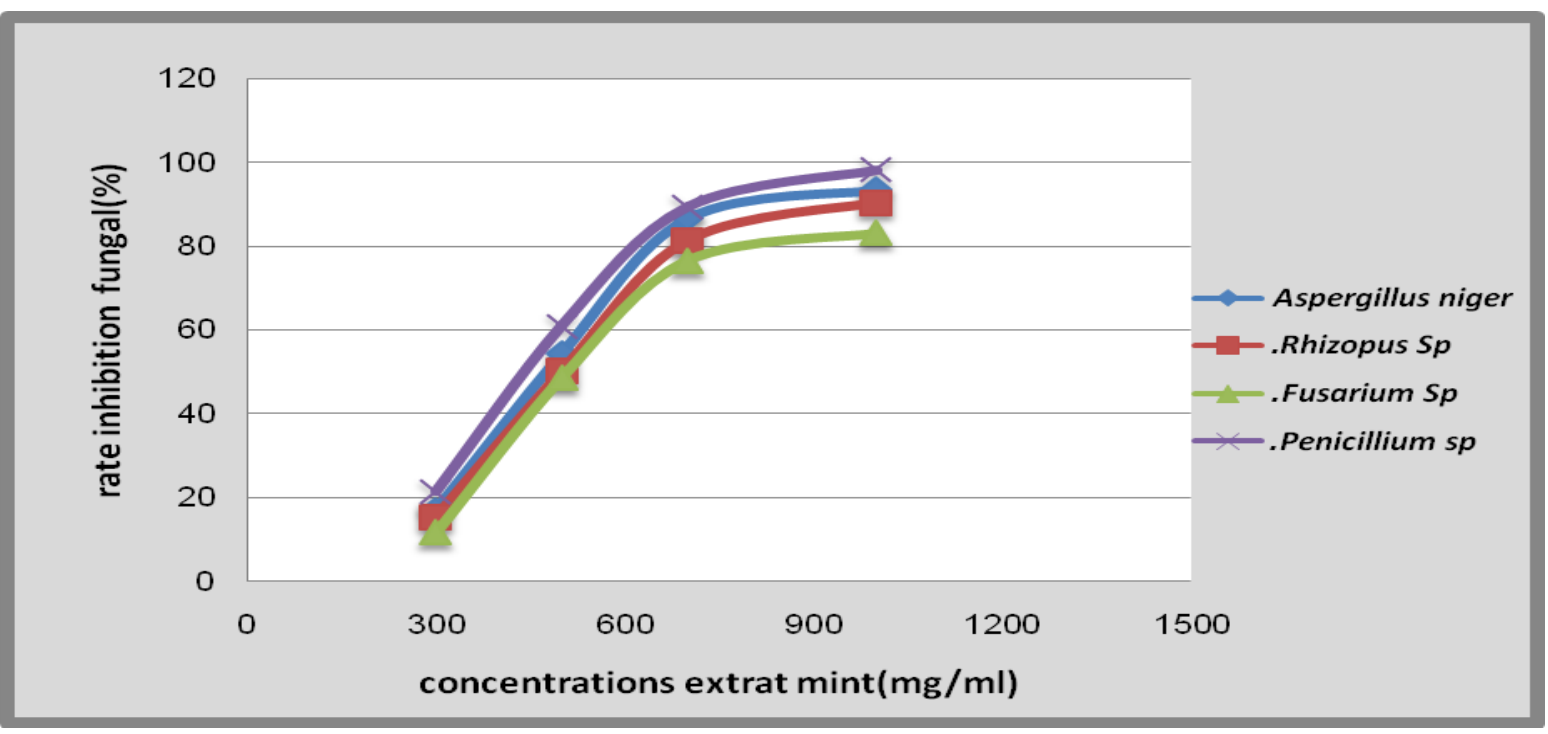

Fig 2 Influences addition concentration different from extract basil on growth some fungal

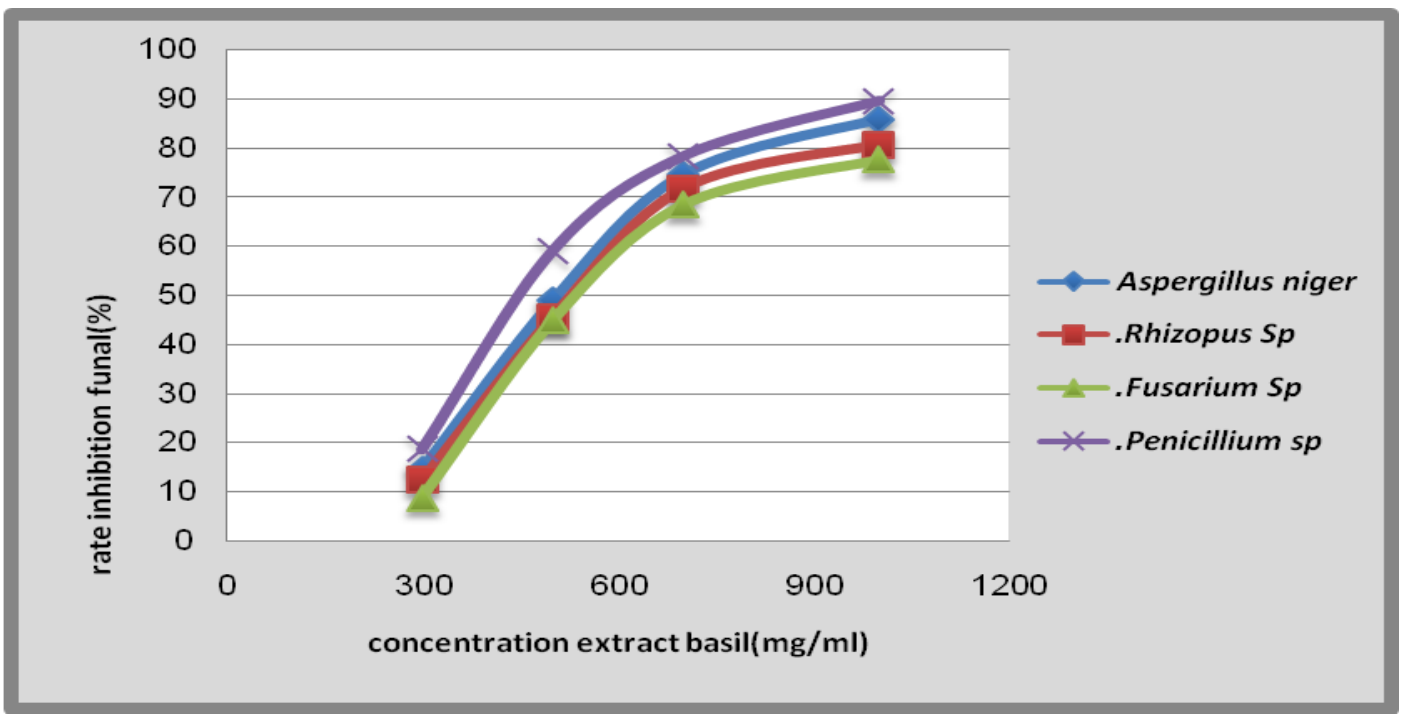


Fig 3 Influences addition concentration different from extract Dill on growth some fungal

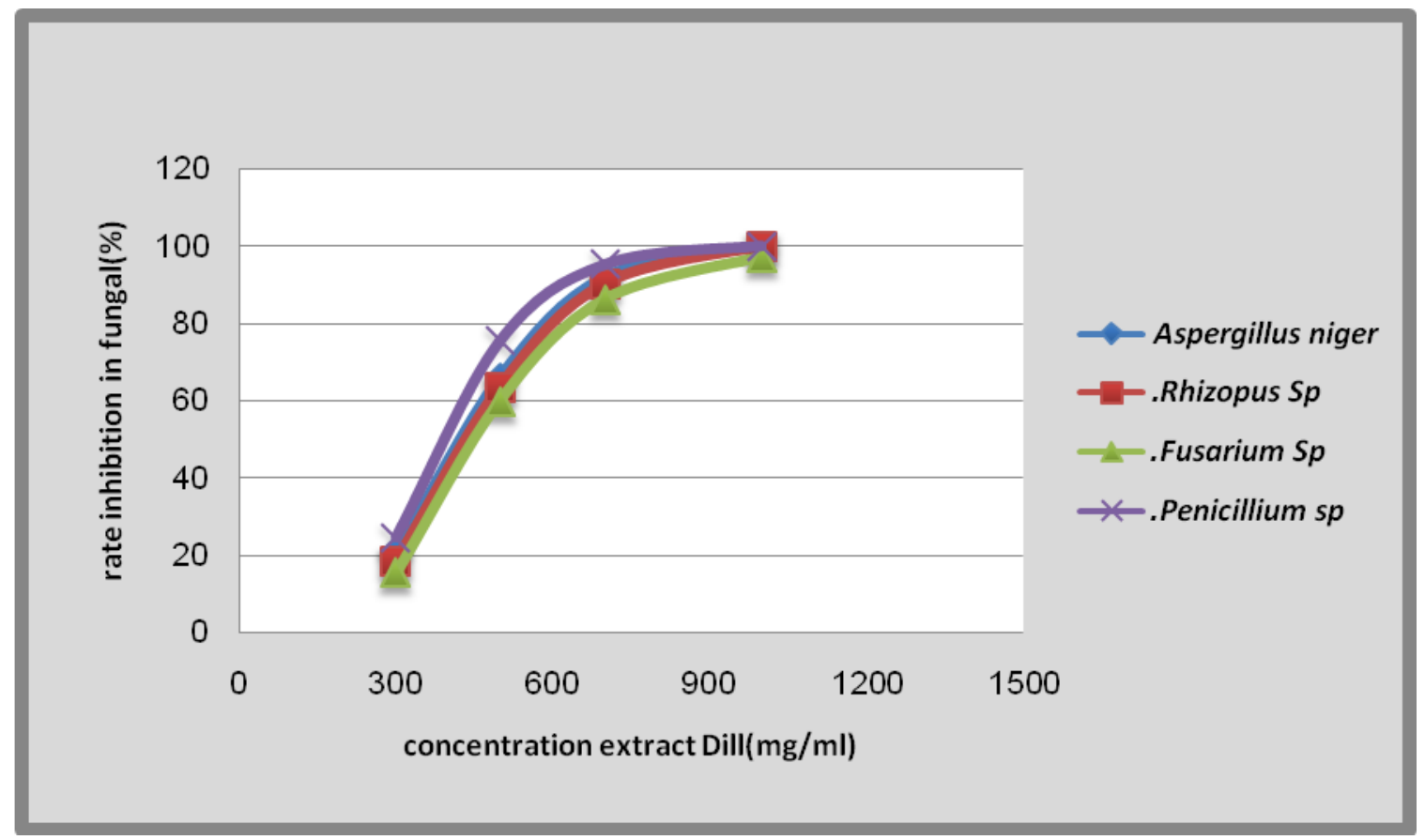

Obvious both (Edeoga et al., 2006; Okwu and Iroabuchi, 2009) if leaves basil contain These products are known by their activity substances such as phenolics, alkaloids, and terpenoids These plants then emerged as compounds with potentially significant application against including bacteria, fungi. Medicinal plants represent a rich source of antimicrobial agents and use

The plant extracts were assayed for antifungal activity against the fungal strain $A$. niger (Bobbarala et al., 2009). This result agreement with (Bidarigh et al., 2012). When uses Preparation of basil Extract different of Solvent Extracts alcohols against fungi.

It has been proved that ethanol extract of $N$. oleander and O.basilicum exhibited the highest activity microbial phytopathogens. This may be attributed to two reasons; firstly, the nature and potentiality of biological active components (alkaloids, flavonoids, phenols, Terpenoids etc).
Inhibition of fungal of the extract Dill

Shown in Table (3) and Fig. (3) the influences Inhibition of the extract Dill against fungal Penicillium sp,Fusarium $s p$,Rhizopus sp, Aspergillus niger of concentration $(300,500,700,1000 \mathrm{mg} / \mathrm{ml})$ and showed extract basil Capability high on Inhibition both, Penicillium sp, Aspergillus niger at concentration $(1000 \mathrm{mg} / \mathrm{ml})$ of rate Inhibition reach $100 \%$ and $100 \%$ on respectively. And influences Inhibition of the extract Dill against Penicillium sp,Aspergillus niger at concentration $(300,500,700 \mathrm{mg} / \mathrm{ml})$ of rate Inhibition reach $24.51, \% 20.78 \%$, $75.36 \%, \quad 65.86, \% \quad 95.34 \%, 92.13 \%$ on respectively, and reach less Inhibition against Fusarium sp, Rhizopus $s p$ at concentration $(300 \mathrm{mg} / \mathrm{ml})$ of rate $15.38 \%$, $18.54 \%$ on respectively. From these results, it was observed that for extract Dill his Capability Inhibition against Penicillium sp do much from lasting fungal were found significant $(\mathrm{p}<0.05)$ between concentration for extract dill. 
Dill has also been used as anticancer; antidiabetic; antioxidant antisecretory; and antimycobacterial and leaves dill contain Chemical structure of major chemical constituents of on types compounds activity (pinene, Limonene, cymene) and dill have property Inhibition against than it Fungus Aspergillus flavus causes direct infections and systematic diseases in humans and lesion in plasma membrane detected through flow cytometry and further verified through the inhibition of ergosterol synthesis And significant reason that dill causes reduction in morphological changes in the cells of aspergillus flavus, as well as a the ergosterol quantity the found compound activity which include (pinene, Limonene, cymene) (Gautam et al., 2013). Some studies reports the traditional use of dill Anethum graveolens green leaves as vegetable, and food flavoring agent and as carminative, stomachic and diuretic (Jana and Shekhawat, 2010; Jinesh et al., 2010).

In conclusion, this paper shows the possible use of extracts plant medicinal in inhibition fungal cause diseases in plant and human with different of concentrations in the range evaluated (300 to $1000 \mathrm{mg} / \mathrm{ml}$ ) were critical in some of the fungal studied against fungal Penicillium sp,Fusarium sp,Rhizopus $s p$, Aspergillus niger especially in dill extract show rate inhibition against fungal rate high.

\section{References}

Al-Ismail, K.M., Aburjai, T. 2004. Antioxidant activity of water and alcohol extracts of chamomile flowers, anise seeds and dill seeds. J. Sci. Food. Agric., 84:173-178.

Bidarigh, S., Massiha, A., Mohammad, R., Pahlaviani, K., Issazadeh, K., Muradov, P. and Azarpour, E. 2012. Antimicrobial (Screening) properties of Various Plant Extracts from Ocimum basilicum L. and Nerium oleander L. against Fungal
Common Rots of Potato. J. Basic. Appl. Sci. Res., 2(7)6810-6815.

Bobbarala, V., Katikala, P., Naidu, C., and Penumajji, S. 2009. Antifungal activity of selected plant extracts against phytopathogenic fungi. Aspergillus niger F2723. Sci. Technol., 2(4): 0974- 6846.

Carretto, C.F.P., Almeida, R.B.A., Furlan, M.R., Jorge, A.O.C. and Junqueira, J.C. 2010. Antimicrobial activity of Mentha piperita L. against Candida spp. Brazilian Dental J., 13(1), 4-9.

Carrubba, A., Matranga, A. and Torre, R. 2002. Cultivation Trials of Some Aromatic and Medicinal Plants in a Semiarid Mediterranean Environment. Acta Hort., 576: 207-213.

Edeoga, H.O., G. Omosun and L.C. Uche. 2006. Chemical composition of Hyptis suaveolens and Ocimum gratissimum hybrids from Nigeria. African J. Biotechnol., Vol. 5 (10): 892-895.

Gautam, P., Singh, K., Kalra, S. and Khanna, D. 2013. Dill herb: Wall Against dysfunctions: an updated profile. Int. J. Recent $A d v$. Pharmaceutical Res., 4(4): 1-8.

Hosseinzadeh, H., Karimi, G.R., Ameri, M. 2002. Effects of Anethum graveolens L. seed extracts on experimental gastric irritation models in mice. BMC Pharmacol, 2: 21.

Jakowinko, P. and Wojcik-Stopczynska, B. 2010. Influence of essential oils from different varieties of peppermint (Mentha x piperita L.) on growth of some filamentous fungi. West Pomeranian University of Technology in Szczecin Słowackiego 1771-434 Szczecin.

Jana, S., Shekhawat, G.S. 2010. Anethum graveolens: An Indian traditional medicinal herb and spice. Pharmacogn Rev., 4(8):179184.

Jinesh, V.K., Jaishree, V., Badami, SH, shyam, W. 2010. Comparative evaluation of edible and non-edible leaves of Anethum graveolens L., Indian J. Natural Products and Res., 1(2): 168-173.

Khair-ul-Bariyah, S., Ahmed, D., Ikram, Aujla, M. 2012. Comparative Analysis of Ocimum basilicum and Ocimum sanctum : Extraction Techniques and Urease and 
alpha - Amylase inhibition. Pak. J. Chem., 2(3): $1-8$

Mahasneh, A.M. 2002. Screening of some indigenous Qatari medicinal plants for antimicrobial activity. Phytother Res., 16: 751-753.

Mahboubi, M., and Kazempour, N. 2014. Chemical composition and antimicrobial activity of peppermint (Mentha piperita L.) Essential oil. Songklanakarin J. Sci. Technol., 36 (1), 83-87.

Manoorkar, B. and Gach, B. 2014. Evaluation of antifungal activity of some medicinal plant extracts against some storage seed -borne fungi of Groundnut. Sci. Res. Reporter, 4(1): 67-70.

Masih, H., Kiran, J. and Tripathi, P. 2014A comparative evaluation of antifungal activity of medicinal plant extracts and chemical fungicides against four plant pathogens. Int. J. Curr. Microbiol. App. Sci., 3(5): 97-109.

Mathur, R. and Goyal, M. 2011. Antimicrobial Potential and Phytochemical Analysis of Plant Extracts of Calotropis Procera. Int. J. Drug Discovery and Herbal Res., IJDDHR.13: 138-143.

Okwu, D.E. 2004. Phytochemicals and vitamin content of indigenous spices of Southeastern 6: 1249-1270. Nigeria. J. Sustain. Agric. Environ., 6(1): 30-37.

Okwu, D.E. and F. Iroabuchi. 2009. Phytochemical composition and biological activities of Uvaria chamae and Clerodendoron splendens. E-J. Chem., 6(2):553-560.

Panda, S. 2008. The effect of Anethum graveolens L (dill) on corticosteroid induced diabetes mellitus: involvement of thyroid hormones. Phytother Res., 22: 1695-1697.

Pandey, D.K., N.N. Tripathi, R.D. Tripathi and S.N. Dixit. 1982. Fungitoxic and Phytotoxic properties of the essential oil of $H$. suaveolenszeitschrift fur pflanzenkraneaten and pflanzenschutz, 89: 344-349.

Pramila, D., Xavier, R., Marimuthu, K., Khoo, M., Senthilkumar, M., Sathya, K., and Sreeramanan, S. 2012. Phytochemical analysis and antimicrobial potential of methanolic leaf extract of peppermint (Mentha piperita: Lamiaceae). J. Med. Plants Res., Vol. 6(2): 331-335.

Prince, L. and Prabakaran, P. 2011. Antifungal activity of medicinal plants against plant pathogenic fungus Colletotrichum falcatum. Asian J. Plant Sci. Res., 1(1): 84-87.

Randhwa, G.S., Kaur, S., Chadha, K.L. and Gupta, R. 1995. Dill: Medicinal and Aromatic Plants, Malhotra Publ. House; 11: 917-932.

Salim, E.T., Y. Al-Douri, M.S. Al Wazny, M.A. Fakhri, 2014. Optical properties of Cauliflower-like $\mathrm{Bi} 2 \mathrm{O} 3$ nanostructures by reactive pulsed laser deposition (PLD) technique. Solar Energy, 107: 523-529.

Schimmer, O., Kruger, A., Paulin, H.F. 1994. An Evaluation of 55 Haefele Commercially pants extract in the Ames Mutagenicity Test. Pharmazie, 49: 448-451.

Zaker, M. 2014. Antifungal Evaluation of Some Plant Extracts in Controlling Fusarium solani, the Causal Agent of Potato Dry Rot In vitro and In vivo. Inter. J. Agri. Biosci., 3(4): 190-195.

Zheng, G.Q., Kenney, P.M., Lam, L.K. 1992. Anethofuran, carvone and limonene: Potential cancer chemoprotective agents fungl and bacterial.

\section{How to cite this article:}

Hasan Kadhim Ali, Ahmed Malik Jumaah, Ahmed Sadoon Hassian. 2017. Studying Efficiency Inhibition of Some Medicinal Plant Extracts against Some Fungal Int.J.Curr.Microbiol.App.Sci. 6(1): 108-115. doi: http://dx.doi.org/10.20546/ijcmas.2017.601.014 